\title{
Global Climate Change as a Challenge to the National Security of Ukraine
}

\section{Olena SHEVCHENKO ${ }^{1}$, Kira HORIACHEVA ${ }^{2}$}

${ }^{1}$ Department of international mediacommunications and communication technologies, Institute of International Relations, Taras Shevchenko National University of Kyiv, PhD (Politics), associate professor, Illienka str. 36/1, 04119, Kyiv, Ukraine

${ }^{2}$ Taras Shevchenko National University of Kyiv, Military Institute, PhD (Economics), associate professor, Kyiv, Ukraine

E-mails: ${ }^{1}$ ovsh@ukr.net; ${ }^{2 h o r y a c h e v a k i r a @ g m a i l . c o m ~}$

\begin{abstract}
The article shows that global climate changes are already visible in Ukraine. At the same time the climatic consequences that Ukraine will face will not be so critical for population incubation, as, for example, in Africa and East Asia. In these regions, the catastrophic decline in drinking water and fertile land will stimulate migration to new territories for survival. Climate refugees, according to the authors, will become one of the main challenges to the national and food security of Ukraine and the European region.
\end{abstract}

KEY WORDS: global climate change, national security, climate refugees, mitigation, adaptation

\section{Introduction}

Climate change is a new threat to international security. The manifestations of global climate change are warming the atmosphere and the ocean, reducing glaciers, rising sea levels, depleting the ozone layer, polluting the forests, desertifying, depleting soils, the problem of mass shortages of food and drinking water, reducing biodiversity etc.

Global climate change is also a challenge for Ukraine. The response to global climate threats was the approval in 2015 of the National Security Strategy of Ukraine, where the effects of climate change are attributed to topical threats to the national environmental security of the state. Threats to environmental safety include, in particular, excessive anthropogenic impact and a high level of technogenic load on the territory of Ukraine; significant amount of waste of production and consumption and inadequate level of their usage, recycling and utilization, etc. [1].

According to international experts, Ukraine is in a temperate climate zone, which is an ideal zone for continued production of agricultural food. Our country does not fall into the territories of increased vulnerability to global climate change and increased risk of «climate wars» for survival. This means that, in the context of temperate climates and environmental livelihoods, Ukraine is becoming a target area for residents of those countries that will be affected by climate change in the coming years. In other words, as a result of global climate change, Ukraine becomes an object of climate migration.

The new realities of global climate change and its impact on international migration flows require further learning of this problem. Unfortunately, the problem of the impact of climate refugees on the national security of the country is poorly presented in Ukrainian literature. Therefore, the study of these issues is an urgent problem in contemporary international relations, and their solution will be of great practical importance.

\section{Method of Investigation}

The complexity and multidimensionality of the problem have determined the methodological basis of the study, which consisted of the principles of objectivity, multifactoriality and systematicity. In this paper, an interdisciplinary method of discourse analysis is considered to be the most productive for studying the impact of global climate change on Ukraine's national security, as it answers the following questions: «what consequences for international security are global climate change, how it manifests today, and what effects will global climate

\footnotetext{
${ }^{1}$ Corresponding author.

E-mail address: ovsh@ukr.net
} 
change bring in Ukraine; what are the threats posed by climate change; and what climate change strategies Ukraine can implement based on international experience».

To determine the impact of global climate change on Ukraine's national security, a systematic approach and a component of it were used as a political analysis that made it possible to present a holistic vision of climate challenges for Ukraine. The comparative method made it possible to collate scenarios of the impact of climate change on Ukraine, other European countries and the most climate-vulnerable countries in the world. Climate migration has been identified by the forecasting method as one of the major threats to Ukraine's national security as a result of global climate change.

The empirical basis of the work was the data of the World Meteorological Organization (WMO), Intergovernmental Panel on Climate Change (IPCC), Adelphi Research Center, Germanwatch, Zoï environment network, Ukrainian Climate Network, and Ecodia Environmental Initiative Center [2-7].

\section{Investigation Results}

\subsection{Global Security Challenges from Climate Change}

The Intergovernmental Panel on Climate Change (IPCC), in its fifth assessment report, showed that in countries where temperatures rose by $2^{\circ} \mathrm{C}$, more people were suffering from water shortages, more extreme hot days, and food shortages are more acute than on the planet, where the temperature has increased by only $1.5^{\circ} \mathrm{C}$ [2]. Global climate change will in the near future lead to increased risks to global security, and will also have implications for Earth's geography, human life and the political map of the world. In particular, it will be shown that:

- the threat of flooding of some island states and territories is arising; the coastal areas of a number of states extending to the seas and oceans (such as Great Britain, Japan, Korea, Italy or Israel) may be underwater;

- the risk of damage to roads, infrastructure, energy systems and industry, and the agricultural sector is increasing due to the extremely hot or extremely cold climate, and energy costs for cooling or warming processes will increase accordingly;

- the risk of disruption of the cycles of production and cultivation of agricultural food and livestock farming is increasing; there is a need for new planning for the cultivation of specific crops, their processing, storage, and storage of food, which defines new challenges to global food security;

- $\quad$ high likelihood of price increases for both food and energy, which will cause a chain rise in prices for other production of goods and services;

- the risk of new diseases and epidemics increases due to changes in the bacterial situation, deterioration of the environment of nature and organisms;

- increasing geopolitical threats to global, regional and border wars and conflicts due to migration pressures on climate-friendly and secure countries. This can lead to a dramatic change in world order and state values;

- there is a risk of changing the political borders of states and contemporary political map of the world.

We can agree with Robson $\mathrm{H}$. that all of mentioned above factors can lead to "one of the most significant global climatic risks that is the relocation of peoples with a purpose to the development of new, uninhabitable, liveable territories or military interventions with the seizure of peoples resettlement territories" [8].

\subsection{Security Challengies of Global Climate Change for Ukraine}

According to the head of the Ukrainian Climate Network I. Yeremenko, "Ukraine has already crossed the threshold of $1.5^{\circ} \mathrm{C}$ and is already experiencing the impact of global warming: wild winds, tornadoes, hailstorms, massive drying of forests in Polesie and Carpathians, protracted peat fires, crumbling of rivers groundwater» [9]. The year 2018 was the warmest in Ukraine for 140 years-period. The manifestations of global climate change in Ukraine have been:

- $\quad$ shift of climatic zones from south to north, increase of the area of the steppe zone of Ukraine. The woodland, which was previously considered an area of excessive moisture, is already suffering from drought, and precipitation becomes more local and is accompanied by heavy rainfall, thunderstorms, floods. The introduction of technology, such as drip irrigation, is expensive but already necessary for the region;

- degradation of land and steppes in southern Ukraine is already underway and will continue; Ukrainian agriculture, on the one hand, is able to cultivate new harvest two to three times a year, and on the other farmers will have to fight for water, protect harvest from new pests and unforeseen weather anomalies [4]. 
- Ukrainian forests are gradually disappearing from new infectious diseases and pests;

- there is a reduction in fresh water, which poses a threat to food production; lack of drinking water will be particularly severe in large cities; due to prolonged drought, rivers will be swept away, and cities such as Kyiv will either have to search for new sources of water or save [6].

- an increase in the level of the oceans according to the forecasting models will lead to the coastal cities of southern Ukraine, such as the Gola Pristan, Zatoka, Lazurne, Ukrainian Venice - the city of Vilkovo on the Danube, by the end of this century will be completely submerged, and Odessa, Mykolaiv, Kherson, Mariupol, Berdyansk will be partially covered by water;

- new diseases spread in the tropics today will come to Ukraine: malaria, dengue, and so on.

Based on the modeling of the global climate change development, we can conclude that the most likely scenarios of global climate change impact for Ukraine will be the effects of rising oceans, lack of drinking water, soil erosion and new diseases.

\subsection{Climate Refugees are a Major Challenge for the National Security of Europe and Ukraine}

In the 21 st century, climate change and its effects will not be the same everywhere. In some continents (Asia, Africa) changes will be catastrophic as they will affect yields. Lack of food and drinking water will cause a large number of people (climate refugees) to migrate.

However, according to IPCC, Ukraine is not one of the countries facing the most severe food consequences of global climate change [2]. This means that, despite soil degradation, reduced drinking water levels and the emergence of new pests, national agriculture will be able to adapt to climate change.

In addition to the territories of Ukraine and Belarus, the entire Eurasian continent, especially the territories of Siberia, the Urals and the Far East, according to scientists, are the most resilient to human (peoples) life in the face of global environmental disasters. This means that such climate and geopolitical changes occurring in Africa and Asia pose a real challenge to Europe's national security, as finding viable territories can lead to new nations entering Europe in their search for a safe living space. As a consequence - the emergence of wars and conflicts for acceptable and safe territories for the life on the Planet.

The emergence of climate refugees is predicted by another IPCC study. According to the "Report on Land and Climate 2019", "the likelihood of human displacement worldwide as a result of a climate change is three times higher than a political conflict" [10]. The report also says that the world's poorest countries are most at risk of displacement. $80 \%$ of displaced persons in the last decade are Asian residents, with more than a third of the world's poorest people living.

According to estimates by the World Bank and the International Organization for Migration, in the next 20-30 years, 143 to 500 million climate refugees are expected to emerge for whom Ukraine and Europe will look very attractive [12-13]. This means that about every 45th person on Earth will have to move due to climate change. According to Germanwatch's report, the countries with the highest climatic risks in 2019 have already become: Madagascar, Pakistan, India, Nepal, Bangladesh, Burma, Thailand, Cambodia, Vietnam, Philippines; the leading countries in the number of migrants due to climate disasters in 2018 were: Nigeria, Kenya, Somalia, Afghanistan, India, China, Burma, Philippines, Indonesia [7].

Countries from which the largest number of refugees come to Ukraine according to Global Report on International Displacement are (in descending order): Afghanistan, Russia, Syria, Angola, Congo, Ethiopia, Sudan, Somalia, Turkey, Iraq, Iran, Uzbekistan, Kyrgyzstan, Guinea, Sierra Leone, Nigeria, Chad, Kazakhstan, Turkmenistan, Tajikistan, Pakistan [11].

Therefore, we believe that climate refugees will be the global threat and the biggest challenge for Ukraine's national security: domestic migrants from the southern territories and foreign climate migrants from the most climate-vulnerable countries.

\subsection{Climate Component of Modern Conflicts}

Already, some communities are completely relocating to new lands because of the growing threat of natural disasters. According to former UN Secretary-General Ban Ki-moon, «the environmental crisis, partly due to global warming, underlies the military conflict in Darfur (Sudan)» [14]. Since the 1980s, rainfall has dropped by 40 percent here, water and food have ceased to be sufficient for all, and in 2003, a war broke out in the country for resources between Arab nomadic herders and sedentary black farmers. The situation is complicated by the intense desertification that is developing in almost half of the country.

Global warming is also seen as one of the key causes of the war in Syria. Since 2006, droughts and massive crop shortages have led to the massive migration (up to one and a half million) of Sunni farmers to cities dominated 
by Alawites, which has increased tensions in interfaith relations and created conflicts over scarce natural resources. The water crisis began, exacerbated by numerous refugees from Iraq. In this context, the Arab Spring began in 2011 and then the Syrian War broke out, with the result that some 5 million people had already emigrated, with 6.6 million more displaced within the country. Although the roots of the Syrian conflict are multifaceted, climate and desertification are elements that are combined with other causes [15]. Another example, in 2011, more than a million people fled from the prolonged drought and armed conflict in Somalia.

\subsection{Ethical Problem of Interaction with Climate Refugees}

Most often, refugee status is granted to residents of countries where there are prolonged armed conflicts, where a person's life is at risk due to nationality, religious and political beliefs, or belonging to some social groups. As has been shown, in the 21 st century, tens of millions of people will be forced to leave their country and become «climate migrants» due to the effects of global warming. The term "climate refugee", "climate migrant" is not yet enshrined in international law, but is already used in media and political rhetoric.

In January 2020, the UN Human Rights Committee ruled that «climate refugees are entitled to asylum and states should not deport migrants who have escaped the effects of global warming, thereby endangering their families, lives and well-being» [16]. The decision was made during a hearing in the case of John Tahiothi, a farmer from the Pacific island state of Kiribati who applied for asylum in New Zealand because of the impact of global climate change on his inability to reside in Kiribati. Although it was denied to the New Zealand Migration Service and the UN Committee on Human Rights, the Committee's decision itself contained wording that emphasized that by deporting climate refugees, countries were in breach of international law. That is, climate migrants, unlike traditional migrants who may be deported, returned to their homeland or not allowed to enter new territory, cannot be evicted because their country's territory has become uninhabitable.

\subsection{International Practice of Climate Refugee Management: Experience for Ukraine}

Some countries that are facing the challenges of global climate change (creating unacceptable living conditions, climate migration) have had some experience in managing climate issues. This experience and practice can be adapted in Ukraine to control and interact with both internal and external climate migrants.

\subsubsection{Development of Relevant Legislation}

Ukraine has ratified the United Nations Framework Convention on Climate Change (UNFCCC), the Kyoto Protocol and the Paris Agreement, adopted the Ukraine 2020 Sustainable Development Strategy, developed a climate change adaptation action plan, etc. In accordance with the provisions of the National Security Law of Ukraine, the environment is part of the national country's security. More than 70 Ukrainian pieces of legislation describe the areas of climate change (including mitigation and adaptation measures and climate refugees) and security. Issues of global climate change as a challenge to national security are constantly raised at meetings of the National Security and Defense Council of Ukraine. This indicates that the country's leadership understands the importance and seeks to control the impact of climate change and national security processes. Climate change research is being conducted, which includes forecasts and studies on the impact of climate change on the country's politics, economy and security.

\subsubsection{Implementation of Certificates for Internal Climate Migrants}

Indicative in this respect is the experience of the Russian Federation, which has also faced a decline in the habitation of some territories due to global climate change. Thus, according to the site of the administration of the Nenets Autonomous Okrug, the evacuation of the population is officially initiated in the region due to the difficult climatic conditions [17]. It is noted that in 2020, 16 families of the district will receive certificates for moving to other climatically favorable regions of the country. The issue is the issuance of state housing certificates for Russian citizens who leave the regions of the Far North and the surrounding areas within the framework of the state program of the Russian Federation «Provision of affordable housing and utilities for citizens of the Russian Federation».

\subsubsection{Purchase of Land in other Countries to Accommodate (Relocate) own Citizens}

Some highly urbanized atolls, according to the UN, are already experiencing an acute shortage of fresh water and housing. While maintaining the current rate of population growth, by mid-century the number of inhabitants of states located on atolls will almost double [18]. Climate change can lead to a critical situation and cause mass migration. Kiribati, Tuvalu, Marshall Islands, Maldives, several Caribbean islands are likely to be 
completely flooded. In this regard, the population will neither be able to move within their country nor receive effective assistance from the state. Some island states are already planning and even do relocating. For example, the Maldives has opened a land purchase fund for 350,000 residents of the country, the Kiribati government has bought land in Fiji for future mass migration, most of the inhabitants of Kiliailau in Papua New Guinea have already relocated [19].

\subsubsection{Migration Restrictions Policy}

Some European countries' policies on non-climate refugees can be adapted to regulate the presence of climate migrants within the territory of the country. Given the ethical side of the issue, namely the fact that the deportation of climate refugees may not be possible due to the lack of resettlement in their home territory, many countries, including Ukraine, will have to accommodate climate migrants on their territory.

One approach may be the EU's experience in introducing quotas for refugees from «third world» countries, ie quantitatively limiting the number of migrants arriving in a country established by host authorities. Quotation is now widely used in the EU to regulate temporary labor immigration, immigration for temporary residence, and immigration for resettlement to permanent residence.

Some EU countries have stated their unwillingness to join migration quota policies. For example, Denmark is pursuing one of the most stringent policies in the area of migration control today. Currently, a foreigner residing in the territory of Denmark can be permanently deported from the country for any offense, regardless of the residence permit and even the real estate in the country. If a foreign migrant has been resident in Denmark for less than nine years, he or she may be deported from the country for any offense involving a sentence of six months' imprisonment. Migrants who have been in Denmark for more than 9 years can be expelled from the country for committing a serious crime against the individual or in the field of drug trafficking. The brutality of the migration policy of the Danish state is a consequence of the problem of the entry into the country of migrants from African and Asian states, which have huge differences in cultural sphere from the bulk of the population of the country. Another very effective measure to limit migration initiated by the Danish leadership is the requirement of compulsory knowledge of the Danish language by migrants wishing to settle in the country.

Adaptation and enforcement of migration restrictions may prevent interracial and intercultural conflicts, as well as clashes on religious grounds.

\subsubsection{International Climate Literacy Programs}

International experience in adapting to global climate change shows that educational attainment, dissemination of climate change issues contribute to common solutions, a coherent policy and a reduction of tensions. Adelphi Resource Center experts believe that setting up an international advisory center can facilitate dialogue and cooperation between different sectors [4]. Such a center will provide information and practical advice on climate change adaptation issues, and the results of monitoring important international projects in this area. Increasing the level of climate education, as well as awareness of climate change issues and ways of interacting with climate migrants will help to increase tolerance of climate refugees and reduce the risk of interethnic conflicts as a whole.

\section{Conclusions}

Climate change is a global problem that does not recognize the borders and well-being of countries. In the coming years, the risk of famine, epidemics and disease will increase significantly due to global climate change. Numerous examples show that in the modern world, every country is experiencing the effects of global warming. Climate change in Europe, including Ukraine, will exacerbate environmental, economic, political and social problems, and the additional climate impact on water, agriculture and the energy sector will have serious security implications.

All countries will have to adapt, but in some territories climate change will make it impossible for people to live their lives. Poor countries are most at risk. The effects of global climate change are exacerbating the climate crisis - in addition to warming, rising ocean levels, decreasing drinking water and anthropogenic emissions, humans (climate migrants) are becoming a further threat. In the coming years, most climate migrants will come from Asia and Africa, home to more than a third of the world's poorest people.

Ukraine, as the EU and Russia, is one of the countries with low vulnerability to global climate change. Therefore, in the coming years, these countries will become popular destinations for climate migrants from vulnerable regions. Climate immigration poses a serious challenge for Ukraine because it can provoke geopolitical conflicts, conflicts over energy, food, water, that is, resources for the survival of large numbers of people. In addition, climatic factors affect other regional features - the political situation, population and its economic protection, the degree of anthropogenic load on the environment. 
The solution to the issue of climate refugees, which is a challenge and a threat to Ukraine's national security, lies primarily in the political, economic and security area. This includes adopting a national climate policy, introducing a unified state system for monitoring and controlling the flow of climate migrants, adequate training of the armed forces, internal troops, civil and epidemiological protection services, disaster medicine, and a significant increase in strategic food supplies.

\section{References}

1. Стратегія національної безпеки України // Урядовий кур’єр, 29.05.2015 — № 95

2. Climate Change 2014: Synthesis Report. Contribution of Working Groups I, II and III to the Fifth Assessment Report of the Intergovernmental Panel on Climate Change [Core Writing Team, R.K. Pachauri and L.A. Meyer (eds.)]. IPCC, Geneva, Switzerland, 2014. 151 pp.

3. Руководство по климатологической практике World Meteorological Organization (WMO-No. 100). Geneva. 2018. 182 p.

4. Маaсc А., Даусс Р., Кутоновая Т., Сантер Е. Изменение климата и продовольственная безопасность в Восточной Европе: Отчет по разработке сценариев - Берлин, Adelphi, 2011 - 62 с.

5. Третье, Четвертое и Пятое Национальные сообщения Украины по вопросам изменения климата. Украӥнська кліматична мережа. Available at: http://climategroup.org.ua/upl/ukr_nc5rev.pdf

6. Вода близько. Підвищення рівня моря в Україні внаслідок зміни клімату (повний звіт за результатами дослідження)/ Голубцов О.Г., Біатов А.П., Селіверстов О.Ю., Садогурська С.С. Центр екологічних ініиіатив «Екодія». Available at: http://ecoaction.org.ua/voda-blyzko-report.html

7. Eckstein D., Künzel V., Schäfer L., Winges M. Global climate risk index 2020. Germanwatch Available at: https://germanwatch.org/sites/germanwatch.org/files/20-2-01e\%20Global\%20Climate\%20Risk\%20Index\%20 2020_14.pdf

8. Robson Н. Глобальные климатические изменения - как вызов национальной безопасности - Available at: http://www.frontnews.eu/news/ru/35778/Глобальные-климатические-изменения-как-вызов-национальнойбезопасности

9. 9. Золотников Я. 80 лет спустя. Все, что нужно знать о глобальном потеплении в Украине Available at: https:/focus.ua/technologies/444121-lokalnoe_poteplenie_kak_otrazitsia_na_ukraine_mirovoe_izmenenie_ klimata 2019-11-12

10. IPCC Report on Land and Climate - IPCC, 2019: Summary for Policymakers. In: Climate Change and Land: an IPCC special report on climate change, desertification, land degradation, sustainable land management, food security, and greenhouse gas fluxes in terrestrial ecosystems [P.R. Shukla, J. Skea, E. Calvo Buendia, V. MassonDelmotte, H.- O. Pörtner, D. C. Roberts, P. Zhai, R. Slade, S. Connors, R. van Diemen, M. Ferrat, E. Haughey, S. Luz, S. Neogi, M. Pathak, J. Petzold, J. Portugal Pereira, P. Vyas, E. Huntley, K. Kissick, M. Belkacemi, J. Malley, (eds.)]. In press. $-34 p$.

11. Global Report On Internal Displacement. Available at: https://www.internal-displacement.org/sites/default/files/ publications/documents/2019-IDMC-GRID.pdf

12. Rigaud K., Sherbinin A., Jones B., Bergmann J., Clement V., Ober K., Schewe J., Adamo S., McCusker B., Heuser S., Midgley A. Groundswell: Preparing for Internal Climate Migration. Washington, DC: The World Bank. 2018. - 256 p.

13. Brown O. Migration and Climate Change. International Organization for Migration, Geneva, 2008. - 64 p.

14. Ban Ki-moon A Climate Culprit In Darfur // The Washington Post, June 16, 2007 - Available at: https://www. washingtonpost.com/wp-dyn/content/article/2007/06/15/AR2007061501857.html

15. Selby J., Dahi O.S., Fröhlich C., Hulme M. Climate change and the Syrian civil war revisited // Political Geography Volume 60, September 2017, Pages 232-244

16. Picheta R. Climate refugees cannot be sent back home, United Nations rules in landmark decision. January 20, 2020. Available at: https://edition.cnn.com/2020/01/20/world/climate-refugees-unhrc-ruling-scli-intl/index.html

17. Жаров Е. Кто такие «Климатические беженцы» // Независимая газета, 09.02.2020 Available at: http://www. ng.ru/vision/2020-02-09/100_200209virus.html

18. Campbell J., Warrick O. Climate change and migration issues in the pacific. United Nations Economic and Social Commission for Asia and the Pacific. Pacific Office August, 2014 - 34 p.

19. Climate Migrants. Report. ESRI, 2017. Available at: https://storymaps.esri.com/stories/2017/climate-migrants/ index.html 